\title{
The Effect of Taxpayer Religiousity, Tax Amnesty, and Tax Sanction on Taxpayer Compliance with Medium Small Micro Business Taxes (Msmes)
}

Tomy Prasetia ( $\nabla$ tomyprasetya20@gmail.com )

The University of Western

Research

Keywords: taxpayer religiosity, tax amnesty, tax sanction, taxpayer compliance, Medium Small Micro Business Taxes

Posted Date: March 31st, 2021

DOI: https://doi.org/10.21203/rs.3.rs-368632/v1

License: (c) (i) This work is licensed under a Creative Commons Attribution 4.0 International License.

Read Full License 


\section{Abstract}

Taxes are one of the supports for in infrastructure development. The existence of taxpayer religiosity, tax amnesty, and ta sanction is also a consideration for taxpayer compliance. infrastructure development comes from Tax Indonesian Budget funds, $70 \%$ of which comes from taxes. this study aims to prove the effect of taxpayer religiosity, ta amnesty, and ta sanction on tax compliance of MSME business actors. the type of research used is quantitative. by using multiple linear regression analysis method with three independent variables, namely taxpayer religiosity ( $\mathrm{x} 1)$, tax amnesty ( $\mathrm{x} 2$ ), and tax sanctions ( $\mathrm{x} 3$ ) with the dependent variable taxpayer compliance on tax MSMEs $(Y)$. the population in this study were micro, small and medium enterprises (MSMEs) and the sample technique used was random samling. the primary data soources used were questionnaires and secondary data sources were data froom journals, books, and the internet related to these issues. the data collection tecnique is done by using a uestionnaire, interview, and documentation. data analysis used validity and reliability tests and hypothesis testing. data analyysis used the structural equation modeling method with the help of SmartPLS softare. based on the research results it can be conclued that 1) there is a significant influence of taxpayer religiosity on taxpayer comliance of Medium Small Mlcro Business Taes (MSMEs) in indonesia. 2) there is a significant influence of tax amnesty on taxpayer comliance of medium small micro business taxes (MSMEs) in Indonesia. 3) there is a significant inluence of tax sanction on taxpayer comliance of Medium Small Micro Business Taxes (MSMEs) in Indonesia

\section{Introduction}

The tax sector is one of the crucial sectors related to its role in helping national development(Leal Ordóñez, 2014). So, it is not uncommon for many parties to say that taxes are the prima donna sector of national development. Infrastructure development is one of the benchmarks for a country's development. As is well known, infrastructure development comes from The Indonesian Budget Funds, $70 \%$ of which comes from taxes (Stupak, 2018)

Tax levies are compelling considering the regulations that have been stated in the law (Groh et al., 2020). So that if someone is caught not paying taxes, that person can be subject to administrative sanctions and criminal penalties. In addition to its benefits for state revenue and infrastructure development, taxes also function to equalize citizens' income (Aničić et al., 2016). Small and medium enterprises or also known as micro, small and medium enterprises are taxpayers who have the obligation to pay taxes (Mukhlis \& Simanjuntak, 2016).

As of July 1, 2018, the government has issued Government Regulations Number 23 of 2018 regarding the new MSMEs final income tax rates (Huda \& Hernoko, 2017). One of the contents of this regulation is the reduction of Final Income Tax rates from the initial $1-0.5 \%$ by requiring the following conditions: 1 ) Individual taxpayers can enjoy $0.5 \%$ Final Income Tax rates within 7 years, 2) Taxpayers for Entities businesses such as cooperatives, limited partnership, and firms can only enjoy a final income tax rate of 
$0.5 \%$ for a period of 4 years and 3 ) taxpayers for limited liability companies (PT) can only enjoy a final income tax rate of $0.5 \%$ for a period of 3 years.

The increase in state revenue in the tax sector is not without obstacles. According to Devos (2014) many factors influence tax compliance. These factors can come from within a taxpayer or factors from outside a taxpayer. The term tax payer is defined as a subject who has the obligation to pay taxes as well as taxes on wealth, income and profits he gets(Schizer \& Listokin, 2012). According toBenk, Slaves, Yüzba, \& Mohdali (2016) taxpayer religiosity can affect taxpayer compliance. Religiosity has a positive effect on tax morale and taxpayer compliance voluntarily in paying taxes (Wahl et al., 2010)

In Indonesia, tax compliance is in the low category when viewed from the high level of development of business entities, especially in micro, small and medium enterprises (Sebhat \& Assfaw, 2019). According to data from the Ministry of Cooperatives, Small and Medium Enterprises in 2018, the number of MSME players was 64.2 million or $99.99 \%$ of the total business actors in Indonesia. With the tax amnesty or tax amnesty, this is good news for MSME business actors(Said, 2019).

Tax Amnesty or Tax Amnesty itself is the elimination of taxes that should be paid by disclosing assets and paying a ransom as stipulated in Law No. 11 of 2016 concerning Tax Amnesty (Huda \& Hernoko, 2017). This law also states that taxpayers only need to disclose assets and pay tax ransom as an amnesty tax on assets that have not been reported so far. Tax Amnesty is a means for the government to increase tax revenue and taxpayer compliance (Inasius et al., 2020). In addition, tax amnesty is a policy that is often applied by many countries, including Indonesia (Said, 2017). Through the tax amnesty, it is hoped that MSME actors can increase their compliance with taxpayers (Sari \& Nuswantara, 2017). Given that the tax amnesty program, in addition to increasing state revenue, also has the aim of increasing tax compliance and to improve a better tax base in Indonesia.

There are three objectives that are targets for implementing tax amnesty in Indonesia (Sari \& Nuswantara, 2017). First, increasing domestic liquidity, lowering interest rates and investment and improving the rupiah exchange rate through the transfer of assets. Second, accelerate tax reform and third, increase state revenue from taxes. Tax amnesty is indeed very beneficial for taxpayers, especially taxpayers who are in tax arrears in extraordinary amounts. Even so, taxpayers are expected to be honest in reporting during the tax amnesty period.

Meanwhile, taxpayers who do not become taxpayers may be subject to tax sanctions or tax sanctions. According to Kamil (2015)states that tax sanctions are a guarantee that the provisions of tax regulations will be followed / obeyed. Or in other words, tax sanctions are a preventive tool so that taxpayers do not violate taxation norms. Taxpayers will meet tax payments if they think that tax sanctions will do more harm to them(Mory, nd). The higher or heavier the sanctions, the more detrimental the taxpayer will be. Therefore, it is assumed that tax sanctions will affect the level of taxpayer compliance in paying taxes.

The legal basis regarding tax sanctions is regulated in each article of the Law on General Provisions of Taxation. Tax sanctions can be imposed if the taxpayer commits a violation, especially the obligations 
stipulated in the Law on General Tax Provisions. In the Taxation Law there are two types of sanctions, namely Administrative Sanctions and Criminal Sanctions(Lisi, 2015). For violators of a taxation norm, there are those who are threatened with administrative sanctions only or criminal sanctions, and some are even threatened with administrative and criminal sanctions. Based on the background described, this study aims to determine the effect of tax payment religiosity, tax amnesty, and tax sanctions on Taxpayer Compliance with Micro, Small and Medium Enterprises (MSMEs) Tax.

\section{Literature Review}

\subsection{Taxpayer Religiosity}

One non-economic factor that has been neglected by most studies and should be investigated further is religiosity. This religiosity is related to the values held by most individuals in general which are expected to effectively prevent negative attitudes and encourage positive attitudes in the daily life of individuals, and therefore, religiosity is considered to positively motivate taxpayers to voluntarily obey the law. taxation law(Pope \& Mohdali, 2010).

Religion is broadly defined in Oxford English Dictionary (2017) as belief in humans in super powers that can control power, especially belief in gods or God who are obliged to obey and perform rituals of worship. Hovey et., Al., (2014)define the term religiosity based on two religious orientations, extrinsic and intrinsic. A person's extrinsic religious orientation can easily be captured based on their behavior such as the frequency of attending worship(Meagher, 2018). Meanwhile, religious intrinsic orientation is related to things that motivate people to internalize and live with religious values in their lives.

In previous research, religiosity was explored mainly based on two perspectives, namely religious affiliation and religious commitment(Pope \& Mohdali, 2010). Religious affiliation refers to certain religious groups adhered to by individuals such as Buddhism, Christianity, Islam and Hinduism. Religious commitment is defined as "the extent to which a person adheres to their religion, values, beliefs and practices, and uses it in everyday life"(Shukor \& Jamal, 2013). Religious commitments are divided into two types:

1. intrapersonal religious commitment that comes from individual beliefs and attitudes; and

2. interpersonal religious commitment that stems from an individual's involvement with a religious community or organization.

Some evidence in previous research shows that religiosity plays an important role in developing positive moral values because all religions promote moral teachings(Johnson et al., 2012). Therefore, it is possible that religiosity can be an effective deterrent against illegal behavior as proven in a number of studies related to crime and delinquency.(Pope \& Mohdali, 2010). Surprisingly, there are few studies examining the role of religiosity in tax compliance or tax avoidance(Pope \& Mohdali, 2010). 
According to Pope \& Mohdali (2010), the significant effect of religiosity in tax compliance research has only been highly emphasized in recent studies. A study by(Welch et al., 1991)is one of the first studies to explore the function of religiosity in inhibiting deviant actions including tax evasion. It found that religiosity had a stronger influence in a community with a greater proportion of non-religious people encouraging people to obey the rules. In another study, the findings based on data collected from Catholic parishioners show that levels of religiosity are proven to "promote a moral climate" in preventing tax evasion for both individual and community religiosity (Welch et al., 1991, 166-1667).

Using the same data from Catholics,Petee, Milner, \& Welch (1994)emphasized that the threat of informal sanctions based on the level of social integration in religion has a significant impact in inhibiting tax evasion. The findings appear to be similar perhaps because the same data source was used in the two studies.Grasmick, Bursik, \& Cochran (1991)measured religiosity based on two dimensions, namely salience religious identity and church attendance, and they found that religiosity was effective as a sanction in preventing tax evasion. Furthermore, religious affiliation is also used to measure individual religiosity, and the findings reveal that fundamentalists are less likely to cheat on taxes compared to those who are not religiously affiliated.(Grasmick et al., 1991). Overall, almost all previous studies exploring the impact of religiosity have focused on the negative attitudes of taxpayers, namely tax evasion or tax cheating.

The importance of religiosity in tax compliance research has recently been explored from a different perspective of taxpayer attitudes, namely tax compliance or tax morale. This is in line with the recommendations for further research made byEiya, llaboya, \& Okoye (2016)to explore religiosity to understand tax compliance issues. The findings of this study indicate that religiosity has a positive impact on taxpayer morale. FindingsKirchmaier, Prüfer, \& Trautmann (2018) reinforces the conclusion that the trend of tax fraud is evident among non-religious persons.

In another study, similar findings were confirmed based on data collected from 47 countries where tax evasion was the focus of the dependent variable (Slemrod \& Weber, 2012). There is a negative relationship between the level of individual religiosity and tax avoidance. Whereas most studies in this area show the positive impact of religiosity on tax compliance or tax avoidance, there are two studies that reject the same idea. The personal integrity of individuals may have a stronger influence on their attitudes regarding tax compliance than their own religious beliefs.

\subsection{Tax Amnesty}

Tax amnesty is the elimination of payable taxes but will not be subject to administrative sanctions and criminal sanctions for disclosing assets and paying a ransom. In its implementation, the ransom will only be subject to treasure bags that have not been reported in the 2015 tax return (Simpen et al., 2019). Tax amnesty is a policy that provides a limited time opportunity for certain groups of taxpayers to pay a certain amount within a certain time in the form of amnesty for tax payable (including interest and penalties) in the past period (Junpath et al., 2016). The tax amnesty is granted for taxes that have not been or have not been fully imposed or collected in accordance with the prevailing laws and regulations. 
The purpose of this tax amnesty is to encourage tax reform towards a more just taxation system and to expand the taxation database that is more valid, comprehensive and integrated, accelerate economic growth and restructuring through the transfer of assets, which will have an impact on increasing domestic liquidity, improving the exchange rate. Rupiah, lowering interest rates, and increasing investment, and increasing revenue from the tax sector, which will be used for financing the country's infrastructure(Prichard, 2010). Tax amnesty (tax amnesty) in Indonesia is carried out over three periods. The first period of tax amnesty lasts from 28 June 2016-30 September 2016, followed by the second period starting from 1 October 2016-31 December 2016. The third and final period of this policy takes place on 1 January 2017-31 March 2017. Tax amnesty is an opportunity for taxpayers to pay taxes with a certain amount including the write-off of interest and penalties without fear of being penalized(Huda \& Hernoko, 2017). The government provides several facilities for taxpayers who wish to participate in the tax amnesty program. The conveniences provided are in the form of low tax rates and several facilities such as:

1. Removal of administrative sanctions,

2. The suspension of tax audits for prosecution for criminal purposes,

3. Elimination of all taxes payable.

4. Termination of tax audit for those who are being audited.

5. Final Income Tax is not imposed for transfer of assets in the form of shares, buildings or land (Anggoro et al., 2020).

The following things can make taxpayers subject to sanctions after the tax amnesty period ends:

1. Taxpayers who provide false reports of their assets.

2. Imposition of sanctions of $200 \%$ of income tax for the discovery of assets of taxpayers who still keep their assets or income through manipulative means after reporting during the tax amnesty period.

3. The discovery of assets that are not reported from taxpayers who do not participate in the tax amnesty program so that the assets are added directly as income and subject to additional sanctions for not participating in the tax amnesty(Fitria et al., 2019).

\subsection{Tax Sanction}

In the taxation law, there are two kinds of sanctions, namely administrative sanctions and criminal sanctions. According to (Rahman, 2017) said that administrative sanctions are payment of losses to the state, especially in the form of interest and increases. Based on Law No. 16 of 2009, there are 3 types of administrative sanctions, namely:

Administrative fines, namely tax sanctions imposed on taxpayers who violate the provisions of taxation laws. 
Administrative sanctions in the form of interest, covering:

Payment interest is interest due to payment of taxes not on time, and the payment is made independently without any tax collection letter, tax underpayment assessment letter, and additional tax underpayment assessment letter invoices. Interest is paid using the SSP. These interest sanctions include: interest due to tax return correction, interest due to installments / postponement of payment, interest due to late payment, interest because there is a difference between actual tax payable and temporary tax.

Collection interest is interest due to tax payments that are not made within the deadline for payment by using a bill in the form of tax return, tax underpayment assessment letter, or additional tax underpayment assessment letter.

Appraisal interest, namely the interest included in the assessment letter for additional tax principal. The interest rate is subject to a maximum of 24 months. Increase administrative sanctions are the sanctions most feared by taxpayers. This is because if these sanctions are imposed, the amount of taxes that must be paid can be doubled. Sanctions in the form of increases are basically calculated with a certain percentage of the amount of tax not underpayment. If seen from the cause, increase sanctions are usually imposed on taxpayers who do not provide the information needed to calculate the amount of tax owed.

Currently, the sanctions for individual taxpayers who do not report their annual SPT will receive a fine of Rp. 100,000 (Simpen et al., 2019). For certain communities, a fine of Rp. 100,000 may be considered insignificant. However, for people who personally have to pay taxes, liability tax is considered a heavy burden because of the lack of socialization, both in print and electronic media for the benefit of paying taxes to the state. For business actors, especially MSMEs who have income but have not been registered on the Taxpayer Identification Number card and do not report annual tax returns and do not receive sanctions from the government, this is where the role of sanctions and outreach by the government and the private sector plays an important role in providing an understanding for reporting returns. annual tax.

\section{Method}

This research is included in quantitative research. This study uses multiple linear regression analysis method with three independent variables, namely taxpayer religiosity (X1), tax amnesty (X2), and tax sanction (X3) with the dependent variable taxpayer compliance on MSME taxes $(Y)$. The population used in this research is micro, small and medium enterprises (MSMEs) and the sample technique used is simple random sampling technique. The primary data sources used are questionnaires and secondary data sources are data from journals, books, and the internet that are related to the problem. The data collection technique is done by using a questionnaire / questionnaire, interview, and documentation. Data analysis was performed by using the validity and reliability test and hypothesis testing. Data analysis uses the Structural Equation Modeling (SEM) method with the help of SmartPLS software. 


\section{Result And Discussion}

\subsection{Convergent Validity}

Convergent validity of the measurement model with reflexive indicators can be seen from the correlation between the scores of items / indicators with a score that construct. Individual indicators are considered reliable if they have a correlation value above 0.60 . Based on the results for outer loading (Table 1), all indicators have loading above 0.50 and are significant.

\section{Table 1. Convergent Validity}




\begin{tabular}{|c|c|c|c|c|}
\hline & Tax Amnesty & Tax Sanction & Taxpayer Compliance & Taxpayer Religiosity \\
\hline TA1 & 0.736 & & & \\
\hline TA2 & 0.810 & & & \\
\hline TA3 & 0.704 & & & \\
\hline TA4 & 0.734 & & & \\
\hline TA5 & 0.782 & & & \\
\hline TA6 & 0.710 & & & \\
\hline TA7 & 0.755 & & & \\
\hline TA8 & 0.765 & & & \\
\hline TC1 & & 0.728 & & \\
\hline TC2 & & 0.724 & & \\
\hline TC3 & & 0.809 & & \\
\hline TC4 & & 0.753 & & \\
\hline TC5 & & 0.790 & & \\
\hline TC6 & & 0.821 & & \\
\hline TC7 & & 0.717 & & \\
\hline TR1 & & & 0.769 & \\
\hline TR2 & & & 0.755 & \\
\hline TR3 & & & 0.749 & \\
\hline TR4 & & & 0.745 & \\
\hline TR5 & & & 0.732 & \\
\hline TR6 & & & 0.728 & \\
\hline TS1 & & & & 0.742 \\
\hline TS2 & & & & 0.740 \\
\hline TS3 & & & & 0.833 \\
\hline TS4 & & & & 0.824 \\
\hline TS5 & & & & 0.765 \\
\hline
\end{tabular}

Validity testing for reflective indicators uses the correlation between item scores and construct scores. From the table above it is known that all dimensions meet convergent validity because it has a loading 
value of more than 0.50 . Reflective indicators are suitable for measuring perceptions so this study uses reflective indicators.

\subsection{Discriminat Validity \& Composite Reliability}

Discriminate validity is measured using the square root of average variance extracted (AVE) value. The recommended value is above 0,5 While testing the composite reliability of the indicator block that measures the construct. A construct is said to be reliable if the composite reliability value is above 0.60 . The results of data analysis showed that the research data met the criteria of discriminatory validity and composite reliability.

\section{Tabel 2. Average Variance Extracted (AVE) and Composite Reliability}

\begin{tabular}{|lllll|}
\hline & $\begin{array}{l}\text { Cronbach's } \\
\text { Alpha }\end{array}$ & rho_A & $\begin{array}{l}\text { Composite } \\
\text { Reliability }\end{array}$ & $\begin{array}{l}\text { Average Variance Extracted } \\
\text { (AVE) }\end{array}$ \\
\hline Tax Amnesty & 0.889 & 0.895 & 0.911 & 0.563 \\
\hline Tax Sanction & 0.840 & 0.842 & 0.887 & 0.611 \\
\hline $\begin{array}{l}\text { Taxpayer } \\
\text { Compliance }\end{array}$ & 0.881 & 0.883 & 0.907 & 0.584 \\
\hline $\begin{array}{l}\text { Taxpayer } \\
\text { Religiosity }\end{array}$ & 0.842 & 0.847 & 0.883 & 0.557 \\
\hline
\end{tabular}

\subsection{Evaluate the Structural Model or Inner Model}

Assessing the inner model is evaluating the relationship between latent constructs as hypothesized in this study, namely how the relationship of the first model examines the effect of Taxpayer Religiosity (X1), Tax Amnesty (X2), and Tax Sanction (X3) on Taxpayer Compliance (Y). R Square test results show that the effect of Taxpayer Religiosity (X1), Tax Amnesty (X2), and Tax Sanction (X3) on Taxpayer Compliance $(Y)$ is 0.735 or in other words, Taxpayer Compliance is influenced by Taxpayer Religiosity, Tax Amnesty, and Tax. Sanction of $73.5 \%$. while the rest is $26.5 \%$ influenced by variables not explained in the study.

\subsection{Hypothesis Testing}

The path analysis results will be used to see the effect between variables by looking at the level of significance between variables, as well as the relationships between variables. To see the level of significance between variables, the research Sig is used, if the research Sig is smaller than 0.05 (Sig < 0.05), then it is stated that there is a significant influence between the variables. If the Sig value of the study is greater than the value of 0.05 ( $\mathrm{Sig}>0.05$ ), then it is stated that the influence between the variables is not significant or can also be seen using the $t$ test. If the value of $t$ arithmetic is greater than the table ( $t$ arithmetic $>t$ table) then the influence between variables is significant. Conversely, if the value of $t$ count is smaller than $t$ table ( $t$ count $<t$ table), the influence between variables is not significant. 


\begin{tabular}{|llllll|}
\hline & $\begin{array}{l}\text { Original } \\
\text { Sample } \\
(0)\end{array}$ & $\begin{array}{l}\text { Sample } \\
\text { Mean (M) }\end{array}$ & $\begin{array}{l}\text { Standard } \\
\text { Deviation } \\
\text { (STDEV) }\end{array}$ & $\begin{array}{l}\text { T Statistics } \\
(\text { IO/STDEV|) }\end{array}$ & $\begin{array}{l}\text { P } \\
\text { Values }\end{array}$ \\
\hline $\begin{array}{l}\text { Tax Amnesty }>\text { Taxpayer } \\
\text { Compliance }\end{array}$ & 0.303 & 0.316 & 0.081 & 3.731 & 0.000 \\
\hline $\begin{array}{l}\text { Tax Sanction -> Taxpayer } \\
\text { Compliance }\end{array}$ & 0.372 & 0.364 & 0.092 & 4.038 & 0.000 \\
\hline $\begin{array}{l}\text { Taxpayer Religiosity -> } \\
\text { Taxpayer Compliance }\end{array}$ & 0.292 & 0.289 & 0.078 & 3.755 & 0.000 \\
\hline
\end{tabular}

\section{a. Path coefficient Effect of Taxpayer Religiosity (X1) on Taxpayer Compliance (Y)}

The statistical calculation results of the effect of Effect of Taxpayer Religiosity (X1) on the Taxpayer Compliance $(Y)$ show that the $p$-value is smaller than the value of $a(0.000<0.05)$. And the value of the pathway (beta) has a positive number, the results are significant and positive. These results indicate that the Taxpayer Religiosity influences Taxpayer Compliance. According toBenk, Slaves, Yüzba, \& Mohdali (2016) taxpayer religiosity can affect taxpayer compliance.

\section{b. Path coefficient Effect of Tax Amnesty (X2) on Taxpayer Compliance (Y)}

The statistical calculation results of the effect of Effect of Tax Amnesty (X1) on the Taxpayer Compliance $(Y)$ show that the $p$-value is smaller than the value of a $(0.000<0.05)$. And the value of the pathway (beta) has a positive number, the results are significant and positive. These results indicate that the Tax Amnesty influences Taxpayer Compliance. Tax Amnesty is a means for the government to increase tax revenue and taxpayer compliance (Inasius et al., 2020)

\section{c. Path coefficient Effect of Tax Sanction (X3) on Taxpayer Compliance (Y)}

The statistical calculation results of the effect of Effect of Tax Sanction (X1) on the Taxpayer Compliance $(Y)$ show that the $p$-value is smaller than the value of $a(0.000<0.05)$. And the value of the pathway (beta) has a positive number, the results are significant and positive. These results indicate that the Tax Sanction influences Taxpayer Compliance. According to Kamil (2015) states that tax sanctions are a guarantee that the provisions of tax regulations will be followed / obeyed. Or in other words, tax sanctions are a preventive tool so that taxpayers do not violate taxation norms. Taxpayers will meet tax payments if they think that tax sanctions will do more harm to them (Nurkhin et al., 2018). The higher or heavier the sanctions, the more detrimental the taxpayer will be. Therefore, it is assumed that tax sanctions will affect the level of taxpayer compliance in paying taxes.

\section{Conclusion}


1. There is a significant influence of Taxpayer Religiosity on Taxpayer Compliance of Medium Small Micro Business Taxes (MSMEs) in Indonesia.

2. There is a significant influence of Tax Amnesty on Taxpayer Compliance of Medium Small Micro Business Taxes (MSMEs) in Indonesia.

3. There is a significant influence of Tax Sanction on Taxpayer Compliance of Medium Small Micro Business Taxes (MSMEs) in Indonesia.

\section{Declarations}

\section{Acknowledgement}

C.A.F gratefully acknowledges the LPDP Indonesia endowment fund for education, Ministry of Finance of the Republic Indonesia for the financial support through the Master Scholarship.

\section{Authors details}

${ }^{1}$ The University of Western, Australia

\section{References}

Anggoro, D. D., Agusti, R. R., \& Sarman, K. S. (2020). Tax Incentive on Subsidized Housing in Kupang City. https://doi.org/10.2991/aebmr.k.201116.038

Aničić, J., Jelić, M., \& Đurović, J. M. (2016). Local Tax Policy in the Function of Development of Municipalities in Serbia. Procedia - Social and Behavioral Sciences.

https://doi.org/10.1016/j.sbspro.2016.05.114

Benk, S., Budak, T., Yüzba, B., \& Mohdali, R. (2016). The Impact of Religiosity on Tax Compliance among Turkish Self-Employed Taxpayers. Religions. https://doi.org/10.3390/rel7040037

Devos, K. (2014). Factors influencing individual taxpayer compliance behaviour. In Factors Influencing Individual Taxpayer Compliance Behaviour. https://doi.org/10.1007/978-94-007-7476-6

Eiya, O., Ilaboya, O. J., \& Okoye, A. F. (2016). Religiosity and Tax Compliance: Empirical Evidence From Nigeria. Igbinedion University Journal of Accounting.

Fitria, D., Abdillah, A., Prasetyono, H., Cahyo, I. D., \& Burhanudin, B. (2019). The Difference of Enterprises Taxpayers Compliance after Tax Amnesty. JEJAK. https://doi.org/10.15294/jejak.v12i1.16555

Grasmick, H. G., Bursik, R. J., \& Cochran, J. K. (1991). "RENDER UNTO CAESAR WHAT IS CAESAR'S": Religiosity and Taxpayers' Inclinations to Cheat. Sociological Quarterly. https://doi.org/10.1111/j.15338525.1991.tb00356.x 
Groh, M., Scheef, C., \& Zellweger, T. M. (2020). Estate Taxes and Business Transfers Across the Globe: A Configurational Analysis. Academy of Management Proceedings.

https://doi.org/10.5465/ambpp.2020.20992abstract

Hovey, J. D., Hurtado, G., Morales, L. R. A., \& Seligman, L. D. (2014). Religion-Based Emotional Social Support Mediates the Relationship between Intrinsic Religiosity and Mental Health. Archives of Suicide Research. https://doi.org/10.1080/13811118.2013.833149

Huda, M. K., \& Hernoko, A. Y. (2017). Tax Amnesties in Indonesia and Other Countries: Opportunities and Challenges. Asian Social Science. https://doi.org/10.5539/ass.v13n7p52

Inasius, F., Darijanto, G., Gani, E., \& Soepriyanto, G. (2020). Tax Compliance After the Implementation of Tax Amnesty in Indonesia. SAGE Open. https://doi.org/10.1177/2158244020968793

Johnson, M. K., Rowatt, W. C., \& Labouff, J. P. (2012). Religiosity and prejudice revisited: In-group favoritism, out-group derogation, or both? Psychology of Religion and Spirituality. https://doi.org/10.1037/a0025107

Junpath, S. V., Kharwa, M. S. E., \& Stainbank, L. J. (2016). Taxpayers' attitudes towards tax amnesties and compliance in South Africa: an exploratory study. South African Journal of Accounting Research. https://doi.org/10.1080/10291954.2015.1070565

Kamil, N. I. (2015). The effect of taxpayer awareness, knowledge, tax penalties and tax authorities services on the tax complience: Survey on the individual taxpayer at Jabodetabek \& Bandung). Research Journal of Finance and AccountingOnline).

Kirchmaier, I., Prüfer, J., \& Trautmann, S. T. (2018). Religion, moral attitudes and economic behavior. Journal of Economic Behavior and Organization. https://doi.org/10.1016/j.jebo.2018.02.022

Leal Ordóñez, J. C. (2014). Tax collection, the informal sector, and productivity. Review of Economic Dynamics. https://doi.org/10.1016/j.red.2013.07.004

Lisi, G. (2015). Tax morale, tax compliance and the optimal tax policy. Economic Analysis and Policy. https://doi.org/10.1016/j.eap.2014.12.004

Meagher, B. R. (2018). Deciphering the religious orientation of a sacred space: Disparate impressions of worship settings by congregants and external observers. Journal of Environmental Psychology. https://doi.org/10.1016/j.jenvp.2017.12.007

Mory, S. (n.d.). Pengetahuan Layanan Kesadaran Wajib Pajak dan Kondisi Keuangan di Wilayah KPP Pratama Tanjung Balai Persandingan UU Perpajakan.

Mukhlis, I., \& Simanjuntak, T. H. (2016). Tax Compliance for Businessmen of Micro, Small and Medium Tax Compliance for Businessmen of Micro, Small and Medium Enterprises Sector. International Journal 
Of Economics, Commerce and Management.

Nurkhin, A., Novanty, I., Muhsin, M., \& Sumiadji, S. (2018). The Influence of Tax Understanding, Tax Awareness and Tax Amnesty toward Taxpayer Compliance. Jurnal Keuangan Dan Perbankan. https://doi.org/10.26905/jkdp.v22i2.1678

Oxford English Dictionary. (2017). Oxford English Dictionary Online. Oxford English Dictionary.

PETEE, T. A., MILNER, T. F., \& WELCH, M. R. (1994). LEVELS OF SOCIAL INTEGRATION IN GROUP CONTEXTS AND THE EFFECTS OF INFORMAL SANCTION THREAT ON DEVIANCE. Criminology. https://doi.org/10.1111/j.1745-9125.1994.tb01147.x

Pope, J., \& Mohdali, R. (2010). The role of religiosity in tax morale and tax compliance. Australian Tax Forum.

Prichard, W. (2010). Taxation and State Building: Towards a Governance Focused Tax Reform Agenda. IDS Working Papers. https://doi.org/10.1111/j.2040-0209.2010.00341_2.x

Rahman, A. (2017). How Do Public Officials Perceive Themselves as Taxpayers? A Study of Effect of Modernized Tax Administration System, Tax Sanction, Tax Service, and Tax Morale on Tax Compliance of Public Officials in Indonesia. https://doi.org/10.2991/icas-17.2017.1

Said, E. (2017). Tax Policy in Action: 2016 Tax Amnesty Experience of the Republic of Indonesia. Laws. https://doi.org/10.3390/laws6040016

Said, L. (2019). MICRO, SMALL, AND MEDIUM ENTERPRISES TAXPAYER PERCEPTION ON THE DETERMINATION OF FINAL INCOME TAX POLICY ACCORDING TO GOVERNMENT REGULATION NUMBER 23 YEAR OF 2018. International Journal of Law, Government and Communication. https://doi.org/10.35631/ijlgc.4150018

Sari, R. I., \& Nuswantara, D. A. (2017). The Influence of Tax Amnesty Benefit Perception to Taxpayer Compliance. Jurnal Dinamika Akuntansi. https://doi.org/10.15294/jda.v9i2.11991

Schizer, D., \& Listokin, Y. (2012). I Like to Pay Taxes: Taxpayer Support for Government Spending and the Efficiency of the Tax System. Tax L. Rev.

Sebhat, W., \& Assfaw, A. M. (2019). Analysis of Tax Compliance and Its Determinants: Evidence from Kaffa, Bench Maji and Sheka Zones Category B Tax Payers, SNNPR, Ethiopia. Journal of Accounting Finance and Auditing Studies (JAFAS). https://doi.org/10.32602/jafas.2019.2

Shukor, S. A., \& Jamal, A. (2013). Developing Scales for Measuring Religiosity in the Context of Consumer Research. Middle East Journal of Scientific Research. https://doi.org/10.5829/idosi.mejsr.2013.13.1884 
Simpen, I. N., Abdi, M. N., Fahlevi, M., Noviantoro, R., \& Muhtar. (2019). The Effect of Socialization, Sanction, and E-Filing on Annual SPT Reporting. E3S Web of Conferences.

https://doi.org/10.1051/e3sconf/201912522001

Slemrod, J., \& Weber, C. (2012). Evidence of the invisible: Toward a credibility revolution in the empirical analysis of tax evasion and the informal economy. International Tax and Public Finance.

https://doi.org/10.1007/s10797-011-9181-0

Stupak, J. M. (2018). Economic impact of infrastructure investment. In U.S. Infrastructure: Government Programs and Economic Impacts.

Wahl, I., Kastlunger, B., \& Kirchler, E. (2010). Trust in authorities and power to enforce tax compliance: An empirical analysis of the "slippery slope framework." Law and Policy. https://doi.org/10.1111/j.14679930.2010.00327.x

Welch, M. R., Tittle, C. R., \& Petee, T. (1991). Religion and Deviance among Adult Catholics: A Test of the "Moral Communities" Hypothesis. Journal for the Scientific Study of Religion.

https://doi.org/10.2307/1387210

\section{Figures}




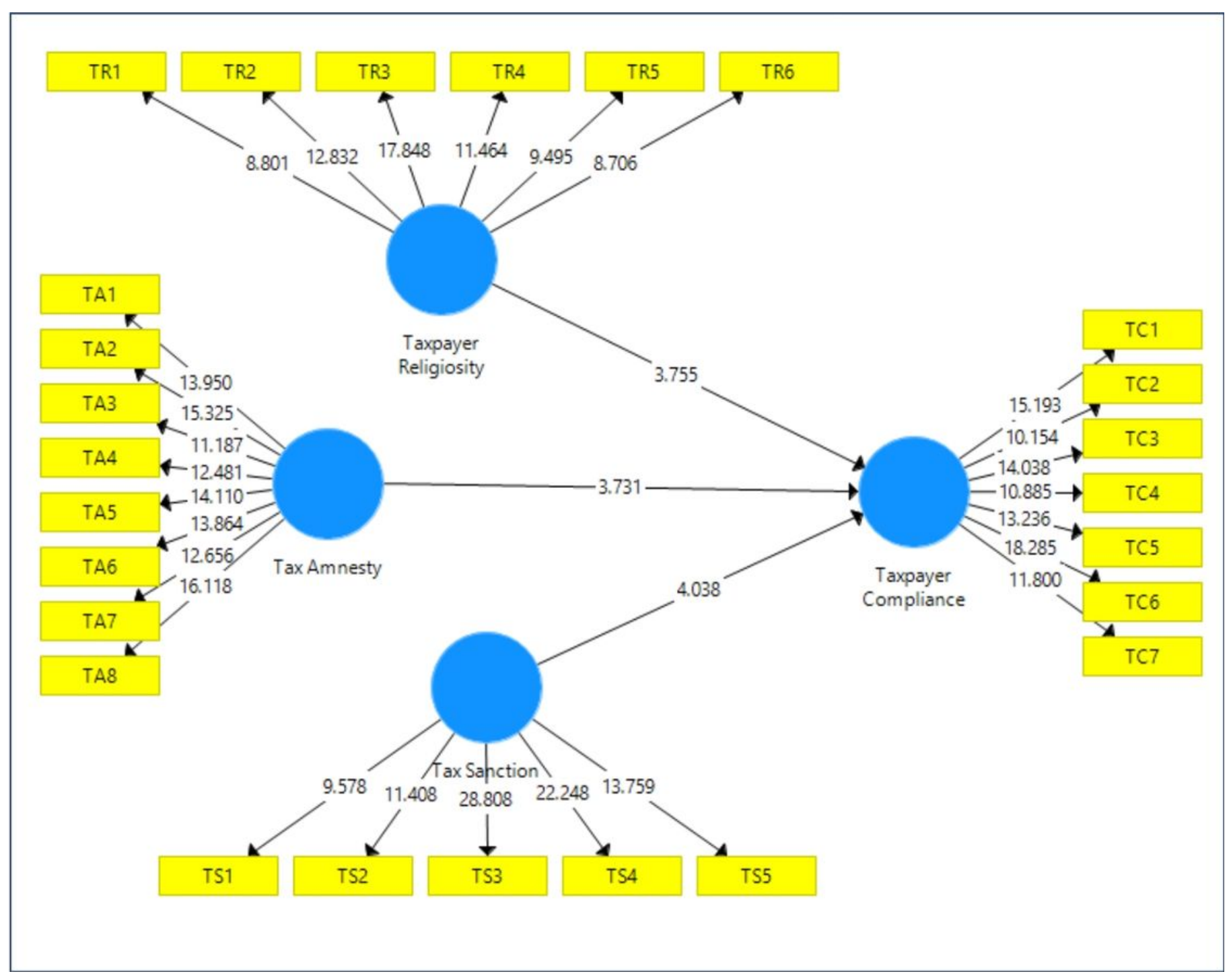

Figure 1

Research Framework 


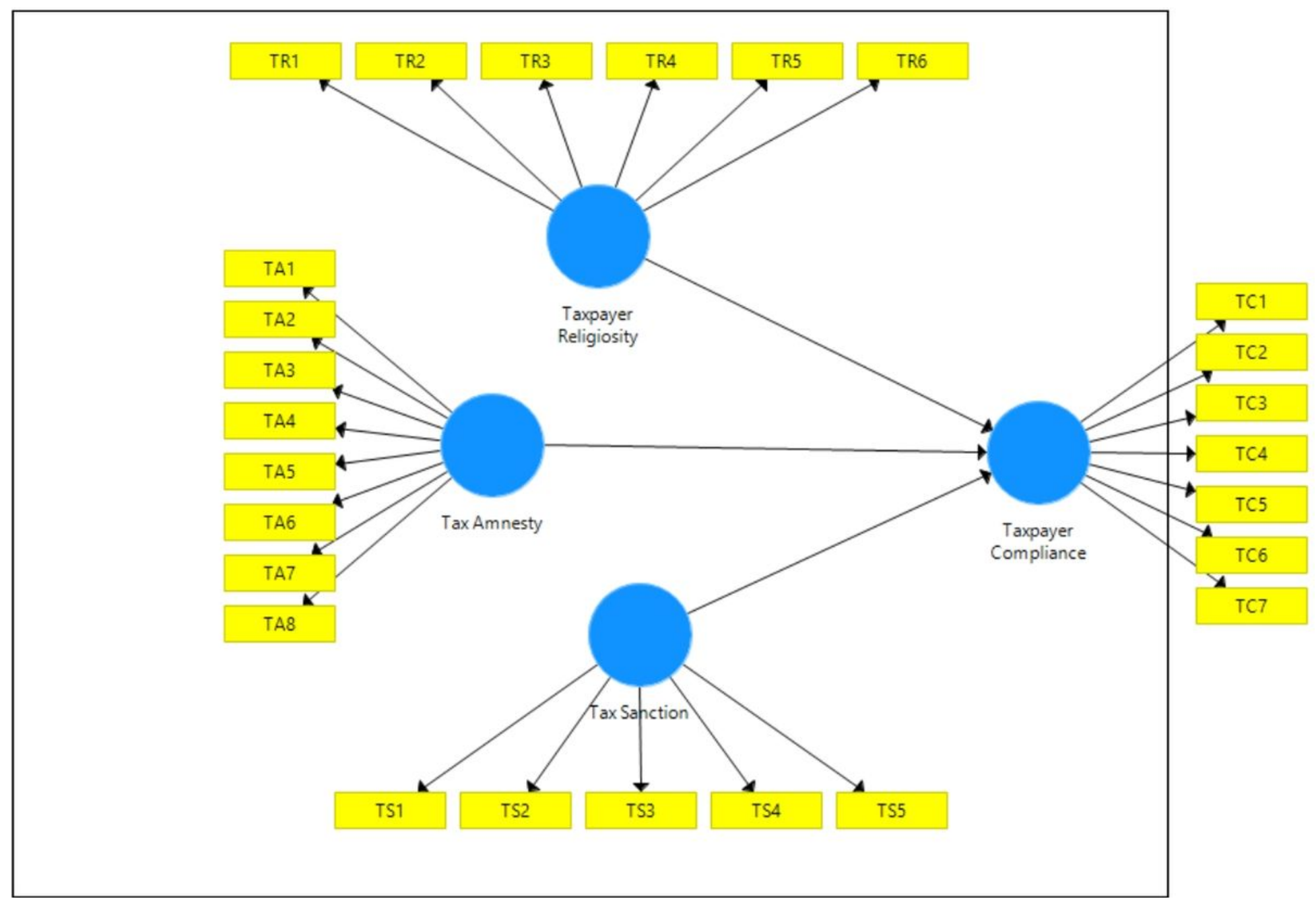

Figure 2

SmartPLS Result 